\title{
TOWARD THE QUESTION OF ESTIMATING THE ACTIVITY OF RONALD REAGAN, A FORMER U.S.PRESIDENT
}

\section{Dr. S.Ishdorj}

It is impossible to elucidate in this small paper multi-sided activity of Ronald Reagan who was a President of the United States for eight years. Therefore I would give you a brief account of his activity mostly connected with relations of two super-powers.

As a result of 1980 presidential election in America from Republican Party Ronald Reagan became a President of the United States.

In most works of the American scholars and historians the Reagan internal and external policy activities were estimated as conservative, because he challenged both at home and abroad. But more or less positive estimation of his activity was given in the works of some other American scholars published in recent years, hi 1984 Reagan was re-elected as a President of the United States of America.

The time was complicated and difficult when Reagan first took the office. The 1970s detente ended. The Soviet Union taking an advantage of priority in balance of forces pursued a so-called "offensive" foreign policy and weakened U.S. positions in Southeast Asia, in the near and Middle East, in Africa and Central America in particular. Moreover, at the end of 1970s the Soviets deployed their SS-20 missiles in Eastern Europe and in December 1979 the Soviet Army committed an invasion onto Afghanistan.

Besides, the Soviet Union together with the Cuban Leadership supporting Nicaraguan Sandinistas and left forces of the other Central American countries encouraged them in taking adventurous actions in order to spread communism over this region.

All these actions of the Soviets and others naturally worsened relations between the two super-powers.

Reagan demanded that the Soviet Union should remove its SS-20 missiles from Eastern Europe and promote the arms control negotiations to reach successes. But Reagan's demand was not met by the Soviets.

In such circumstances, when the Soviets only leaned upon strength, the Reagan Administration had no other way than to take a decisive on reaching equality and prevailing in balance of forces. 
Hi the first term of his presidency (1981-1984) Reagan paid main attention to internal matters of the country. For the purpose of reaching an equality and priority in balance of forces he mobilized financial and economic reserves of the country as well as intellects and abilities of the American people. He also drew a necessary attention on the country's foreign policy.

Reagan stated that he would talk tough to the Soviet Union and take a firm position toward it. He hurled insults at the Soviet Union calling it: "an evil Empire", and it "attempts to restore Asian hordes" and so oh.

hi the fields of economy Reagan carried out a policy on making Americans rely more on the private sector and less on the federal Government, on sharp reducing high percent inflation and cutting taxes. All this brought many negative consequences than positive results. His policy of increasing the productivity by means of encouraging the private sector failed. Reagan reduced spending for social programs, and dramatically increased spending off defense.

Reagan revived two- weapons systems-the MX missile and B-l bomber which had been cancelled by the Carter Administration. He ordered to produce Trident submarines and allowed American arms manufactures to sell arms at the record level.

Space-based Strategic Defense Initiative (SDI) proposed by Reagan in March 1983 was the most expensive weapons system ever devised. The United States became to spend annually 200-300 billion dollars for defense.

This large increase of spending for defense roused the budget deficit and the growth in the National debt. The budget deficit in its turn led to the reduction of investment in modernizing business. American productivity declined, leaving the United States less able to compete with such countries as Japan and West Germany. Even the United States became to borrow money from these countries in carrying out the SDI program. The country was importing more than exporting.

Living standards of the population brought down and the lives of families with fewer incomes became to experience difficulties.

Inside the country Reagan was subjected to severe criticism and accusation, hi the second term of his presidency he continued to fulfill the SDI program.

Despite such not an easy situation Reagan managed to achieve his goal of getting an equality and even superiority in the balance of forces that would be one of the conditions for a successfully carrying out his policy on the international arena. Simultaneously he underlined that U.S. priority in the balance of forces would not mean to unleash war with the other super-power. 
By 1985 cur-relation of nuclear forces between the two super-powers and between the two military alliances-NATO and WTO was as follows: In strategic weapons, the United States had more than 9,000 nuclear warheads on bombers and missiles, the Soviet Union more than 7,000. These were aimed at targets inside the other super-power's homelands. In theater nuclear weapons, the Soviet Union had 3,580 of all types (land-and sea-based) directed at targets in Western Europe, while NATO had 4,445 (including 98 French and 64 British theater nuclear missiles) aimed at Eastern Europe and the Western sections of Soviet Union.

In response to the Soviet emplacement of more than 345 SS-20 missiles (modern intermediate-range weapons with three nuclear warheads each) the United States accordance with the NATO decision started to deploy 500 American cruise missiles in Western Europe.

The basic approach of the Reagan Administration policy on the international arena was to correct the shattered position of the United States and take again a leading place in the world, and to put end to the Cold war which had been continued for several decades.

The Cold/war was a political, economic, ideological, military and diplomatic struggle between "capitalist" and "socialist" systems. The United States of America was at head of the "capitalist" system and the Soviet Union headed the "socialist" one.

In the Cold war under false pretense of "peaceful co-existence of the countries with different social systems" and "peaceful competition" the two superpowers in reality attempted to go get a priority in balance of forces and while doing so weakened an influence and position of the one in some parts of the world, and enlarged and strengthened its influence and position.

Reagan considered the policy on an endless continuation of the Cold war and "containment" of the Soviet Union to be meaningless.

The most important task for him was to avoid nuclear war. His statement: "A nuclear war cannot win and must never be fought" witnessed to this.

Then, Reagan believed that the task for ending the Cold war policy would be reached by means of normalization and improvement of relations between the two super-powers, stopping their interference in conflicts of the third countries, conclusion of treaties on arms reduction and control, and by changing the social systems in "socialist" countries. This last point of changing social systems in communist countries would not be done from abroad, but only be carried out by the people of a giving country. 
In the circumstances when any of the "socialist" countries chooses the road of social transformation and market economy system the United Stated would not be in position of watching, but would render the giving country an economic and other assistance in overcoming its difficulties.

Reagan, U.S. President began to take some steps toward ending the Cold war policy.

In 1983-1984 when U.S.-Soviet relations sharply worsened the Reagan Administration sent the Soviet leadership a message, in which the United States expressed its desire to normalize American-Soviet relations and was still interested in negotiating their differences. But Soviet propagandists accused Reagan of blaming all the ills of tensions in bilateral relations and on an international arena and rejected the American initiative on good cause, as means of disappointing the world public.

In connection of worsening the U.S.-Soviet relations there were written in our propaganda of that time that Reagan was a "warmonger" and wanted to "unleash war" and etc. All those writings of our propaganda did not at all correspond to the complete reality. Indeed, Reagan was not a warmonger and he had no desire to be in war with the other super-power.

One of his attempts to put an end to the Cold war was Reagan's speech in June 1987 in West Berlin. He goaded Gorbachev, when he challenged him to "tear down" the Berlin Wall. To most observers, it seemed to' be an irresponsible provocation, as almost no one in the world expected the Berlin Wall to tear down in the 20th century or even the twenty first.

But the Reagan speech was not a provocation, he had looked through an event which should take place in the nearest future as a step to ending the Cold war. The Berlin Wall symbolized as a statue of the Cold war which could be considered as a small "iron curtain" inside a large iron curtain. Therefore his calling Gorbachev to tear down the Wall contained thought of great importance that would be proved by coming events of that time.

An important step to ending the cold war became a transition of the two super-powers into negotiations on improving relations between them and conclusion of a certain treaty on arms reduction and control.

Substitution of the old Soviet leadership by M.Gorbachev, a man with new thinking to carry out social and economic reform in his country favorably influenced on normalizing and improving U.S.-Soviet relations, on negotiating to stop arms race, reduce arms, and conclude an agreement or treaty.

Gorbachev believed that normalization and improvement of Soviet-Ameri- 
can relations would help him to reduce military expenditures and promote his social and economic reform in the country.

During the second term of his presidency Reagan stopped hurling insults at the Soviet Union. He was sure that, like Nixon had opened the door to China he could start with the Soviets to negotiate on arms reduction. At the same time Nancy Reagan urged her husband to negotiate with the Soviets so that he would be known in American history as a "peace president". If he could do it nobody dared to accuse him of being soft on communism and neglecting the national security. There were also other people who had the same opinion.

Reagan and Gorbachev met four times in summits (in 1985-Geneva, in 1986- Reykjavik, in 1987-Washington and in 1988-Moscow) each of these meetings had its significance.

As one of the points of agenda at Geneva summit meeting the United States has prepared a proposal on stopping Soviet-American involvement in conflicts of the third world along with the questions of improving relations of the super-powers and of arms reduction and control. The American proposal consisted of:

a) Both countries would encourage parties to regional conflicts to start negotiations for a peaceful settlement;

b) Once negotiations took hold, U.S. and Soviet representatives would decide how to halt the flow of arms to the parties from the outside;

c) When peace was established in the area, the United States and Soviet Union would cooperate in assisting economic reconstruction.

At the Geneva summit Gorbachev rejected Reagan's proposals on stopping Soviet-U.S. involvement in the third countries, on guarantee of human rights and free exchange of people between them, but he only accepted Reagan's proposal on developing and enlarging Soviet-American trade and cultural relations.

Paying his main attention to arms reduction Gorbachev proposed Reagan to refuse from deploying American cruise missiles in Western Europe and in that case he would remove the Soviet SS-2O intermediate-range missiles from Eastern Europe while leaving such number of missiles equal to numbers of French and English missiles. Reagan rejected this proposal. Simultaneously Gorbachev asked Reagan to refuse from carrying out "Strategic Defense Initiative". In response to his request American President explained that if the arms control talks failed, SDI would substitute this failure and therefore, he could not refuse from SDI. 
So, any agreement or treaty was not signed at Geneva summit and only a joint Statement was published.

But it would be a mistake to consider the Geneva summit as a failure. Altogether 2-3 years before the Soviet-American relations had been on the brink of war now as a result of the summit meeting the tensions were weakened and the two super-powers in some extents have already found a common language. The joint Statement underlined that the two countries in their relations would "prevent war whether nuclear or conventional, or any other war between them". It was an event of great importance.

In early fall of 1986 Gorbachev sent Reagan a secret message in which he proposed a quick "preparatory" short meeting be held in a third country. He suggested Reykjavik, Iceland. As the preparatory* meeting was destined for a Washington summit Reagan agreed to Gorbachev's suggestion. On November 11 and 12, 1986 they met in Reykjavik and had talks. For Gorbachev, arms reduction and control was the key issue, for Reagan was important, but only a part of broader agenda.

Gorbachev presented a detailed proposal for a comprehensive arms reduction and control agreement in which, gradually he was making major concessions. But his proposal offered very little in the other points of agenda. In his proposal Gorbachev was accepting the U.S. proposal for 50 percent reduction in heavy land-based missiles, low numbers of intermediate-range missiles, broad on-site inspection.

At the afternoon session of second day only two issues of principle remained. Firstly, Gorbachev had proposed to eliminate all nuclear weapons by the year 2000, while Reagan had offered to eliminate all ballistic missiles. Secondly, Gorbachev insisted all researches on strategic defense be confined to laboratories, to which Reagan didn't agree. He explained that testing outside laboratories would be essential to the program.

In order to appease the Soviet leader Reagan accepted Gorbachev's proposal for eventual elimination of nuclear weapons but fused on SDI testing.

Gorbachev stated that he would fulfill his proposal of accepting the U.S. positions on condition that the agreement precludes the .sudden deployment of strategic defenses by the United States.

Since laboratory research was more important than testing in space at that stage of research in both of countries, the United States have accepted some limitations without crippling the program.

The Reykjavik meeting carved the way for a conclusion of new treaty next year. 
In July, 1987 in Geneva the Soviets presented a new arms reduction proposal, to which the United States agreed. It called for a world wide elimination of all U.S. and Soviet short-and medium-range missiles.

In December, 1987 Gorbachev visited to Washington. Here in American Capital at a summit meeting Gorbachev and Reagan signed the intermediate nuclear force treaty, which called for dismantling and destruction of all shortand medium-range missiles, with provisions for a system of independent, onsite verification and weapons inspection.

This INF Treaty was a great breakthrough in the cold war. It also could be considered as a large step toward ending the cold war. Gorbachev and Reagan solved more disputed problems than leaders of the two super-powers had at any previous U.S.-Soviet meetings.

The treaty is considered as an event of great importance in present international political life. Many questions, connected with world peace and security now and in future will be solved only through the way of the INF Treaty.

In spring of 1988 Ronald Reagan visited Moscow. The talks and negotiations between Gorbachev and Reagan on reduction of strategic weapons ended without results. The reasons for this were: the latent persistence of conservatives on both sides, the strength of legacy of mutual mistrust and limits on the powers of two leaders.

The most decisive factor in ending the cold war was a change of social systems in communist countries. When Reagan visited Moscow Gorbachev's reform entered the fourth year since its beginning.

At this time the final goal of the Gorbachev reform was still indefinite. Despite Gorbachev's public statement of transition into multiparty system, pluralism and market economy the Soviet society tested many negative facts such as a decline of discipline, disorders, increase of hard drinkers and crimes, hi brief, the Soviet society tested not an easy situation.

Taking onto an account of these circumstances Reagan evidently decided to encourage Soviet public toward human rights, freedom and democracy.

On the other side, Gorbachev's social and economic reform naturally attracted the attention of foreign countries, first of all, the United States.

Therefore, when Reagan's stated goal or reduction of strategic weapons was not reached, he decided to promote the Gorbachev's reform.

During one of the breaks in his meeting with Gorbachev the two leaders strolled on Red Square. The crowd was sparse, since KGB security agents had kept most tourists at distance, but Reagan greeted a couple with a baby and 
took it on his arms: typical act by a politician when cameras are around, but in this case it seemed to symbolize much more. Realizing that he was in the symbolic center of the Soviet Union, the American President demonstrated that there are human qualities that unite all peoples. He was no longer dealing with a hostile adversary but with human being struggling, as we were, to find the way to a peaceful and more prosperous life.

Reagan used his free time and took an unscheduled walk along the Arbat Street of Moscow, mixing the crowds. He got acquainted with the lives of ordinary people and with the Russian culture and history.

When he called on American Embassy in Moscow and was met by 96 Soviet dissidents. Reagan received them and spoke with an address, in which he stressed the necessity of defending the rights of individuals and establishing democratic institutions in the Soviet Union.

At Moscow University he addressed to the students and stated that the key to progress "is freedom-freedom of thought, freedom of information, and freedom of communication". Then he spoke on the necessity of combining the concept of political and economic freedom with the Russian tradition, and in conclusion of his address he once again outlined "his dream of a world without barriers that obstruct travel and the interchange of ideas, much as he had in Washington in the summer of 1984, when he had called for broadened U.S.Soviet cultural contact".

Andrei Voznesensky, Soviet poet, characterizing Reagan's visit to Moscow at that time said: "Reagan's visit is one of the greatest event in all of Russian history... Reagan's words and gestures had emboldened reformers throughout the country. Russian intellectuals had habitually doubted the capacity of their own country to absorb democracy, but Ronald Reagan, a man who could not be accused of closing his eyes to Soviet reality, had faith in them. That would encourage Soviet citizens to put an end to their traditional political passivity and start taking their future into their own hands".

In brief, Ronald Reagan, American President made a very deep impression on the Soviet public. No single visit of a foreign statesman could have such a profound impact on a nation's self-confidence as to alter the course of its history. At the same time, there was something to what Voznesensky said. Reagan's encouragement of democracy in the Soviet Union came at critical time, and his earlier no-nonsense condemnation of communism gave his words of encouragement a credibility that less outspoken public figures could not command.

Recently Ronald Reagan's activity has been becoming to be estimated 
positively and his popularity is increasing. An evident proof of this was the result of American voters' poll. Concerning estimation of the activities of nine U.S. Presidents from Herbert Hoover to Ronald Reagan (John Kennedy who worked for three years as a president and who was assassinated not included here) the voters' poll showed that three out of four voters had judged only three presidents (Franklin Roosevelt, Dwight Eisenhower, and Ronald Reagan) as competent.

So, Ronald Reagan's activity had both of dark and bright sides. Despite 3 trillion dollars' national debt, despite Iran-contra, despite severe domestic scandals and criticism, despite his flip-flops from arms builder to arms destroyer and from seeing the men in the Kremlin as the focus of evil in the world to becoming the number-one fan of Gorbachev Reagan had also bright sides in his activity of U.S. President. Now the American people began to estimate the bright sides of his activity. The most important bright side of the Ronald Reagan activities as a U.S. President was fulfillment of if not eighty, but not less than sixty or seventy percent of his tasks for putting an end to the cold war.

\section{A List of the Used Books}

1.Frank W. Box and Clayne L. Pope. America: A Study in Heritage. An International Disciplinary Approach. 7th Edition. Kendall / Hunt Publishing Company, 1993, Dubuque, Lowa

2. Winthrop D. Jordan, Miriam Greenbelt, John S. Bowes. The Americans. History. Ml McDougal, Little \& Company, 1992, Evanston, Illinois

3. Martin McCauley. The Origins of the Cold War. 1941-1949. Second Edition. Longman, London and New York, 1996

4. Jack F. Matlock. Autopsy on an Empire. 1995, Random House, New York.

5. Stephen E. Ambrose. Rise to Globalize. American Foreign Policy since 1938. 7th Revised Edition. Penguin Books. 1993

6. The Strategic Quadrangle. Edited by Michael Mandelbaum. Council on Foreign Relations Press. New York, 1994. 